\title{
Weapons at Sea
}

\section{The Place of Aircraft and the Battleship

\author{
By Commander E. G. Allen, U. S. N.
}

A WEAPON in war, theoretically, depends for value A upon its armament, protection and mobility; and, for practicability, given an employment of it, upon its destructive power, the ease and economy of its employment, and the relative protective measure afforded while using it, compared to the relative protection which can be used to frustrate it or stand up under its blows. In new departures in warfare, and with new weapons. the offense is normally developed, initially, at a rapid the offense is normally developed, initially, at a rapid time this is largely due to secrecy and the tremendous energy put into the design, production and employment of the new weapons; while in peace time, inertia, conservatism, and lack of vision with respect to new developments, produce the same effect. Disaster in sight is what quickens the vision and produces the energy to enable defense to obtain rapid development. So, it usually occurs that, given disaster ahead, defense is accelerated and eventually catches up. Its rate of overhead depends, in peace time, upon the vision, energy, and persistence of the responsible officials, and, in wartime, upon the urgency of the necessity-at home, upon the inventiveness, money, and available production facilities, and, in the field, upon strategical dispositions and the tactical ingenuity of leaders.

This is applicable ashore and afloat and has been the history of development in all warfare. We may assume that with the first development of the stone axe and the bow-and-arrow by prehistoric man, rough helmets and shields appeared almost simultaneously; and, in later periods as lance, sword, and cross-bow came into existence, chain armor and similar defense paralleled the offense.

In the late war, such developments as the submarine, tank, gas, and machine gun, and massed artillery with explosive shell and gas, caught the defense lagging materially and tactically. Aircraft came as a distinct innovation and the defense is still not perfected mainnovation and the defense is still not perfected ma-
terially or tactically ashore or afloat. Aircraft, if counter air defense is neglected, has under the theoretical value of a weapon, namely armament, protection and mobility, tremendous values. As armament it can carry gun, bomb, or torpedo; while protection is assured by operating at will in a medium heretofore yet achieved by man in a weapon.

This feature, the retardation of defense development in peace, was illustrated by the status of the submarine in the late war. Great Britain, with a huge sea commerce, her home government centered in a small island, located near probable enemies, and dependent for existence on sea-borne commerce; had lacked ordinar foresight and vision in perfecting her submarine defense. Similarly, the underwater protection of her capital ships had lagged behind torpedo development Necessity in war compelled her to perfect this antisubmarine defense in two years.

The initial destruction wrought by the submarines, tremendous in its effect, brought the usual storm of fanaticism relative to the value of the submarine as a weapon. In this country a serious move arose to intrust the entire national defense at sea to the underseas boat. The submarine has now, in a large measure, found its place; its proper value and its limitations are recognized. Defense against it is to a great extent perfected materially and tactically. It is almost beyond a possibility that in a future war the defense could lag to such an extent that the submarine should be the determining factor of the war.

The advantage gained by the submarine is not in a new armament, but in the relative protection it secures from invisibility in approach, attack, and getaway. Absolute cover from vision is its prime asset.

Aircraft has not this advantage, its primary asset being mobility, rendering surprise easy Aircraft will employ no new armament, and the defense is given the same old problems, namely, to combat bombs, torthe same old problems, namely, to combat bombs, tor-
pedoes and gas fire, when used with great mobility in war. The defense at sea against aircraft is an easier problem than submarine defense, because aircraft is not invisible. It is both visible and audible, and defensive measures can be positive in that the attack is located and fixed by vision and sound.

By water-tight subdivision and armor, the capital ship already has in a large measure protection against the weapons enumerated, namely, bomb and torpedo, and can be made immune by simple arrangements against gas. With the addition of more horizontal or deck armor, the aircraft bomb can be discounted as a serious weapon against such armored ships. Against merchant vessels, destroyers, light cruisers, or plane carriers, the aircraft bomb has a case.

Counter-air-defense is, logically, the major counter against air attacks, and anti-aircraft gun defense is the secondary counter. Afloat, anti-aircraft guns should be of more value than ashore for the following reasons: Afloat the battery is always at the scene of the object to be protected; ashore, the anti-aircraft defense is usually spread out to cover a line. Once ove this line, the bomber drops his bombs at leisure unles the object to be bombed has additional local defense At sea, there is, over each particular ship, a limited vertical rectangular area bounded by the height and speed of the bombing aircraft in which such aircraft must be to hit the ship. If not in this area, when dropped, the bomb misses. Counter air fixed-barrage can be adjusted to keep high-explosive shell bursting in this area, rendering bombing unsafe and difficult. This secondary defense must, of course, be supplemented by a major one employing protective pursuit planes. These combined defenses, properly organized, should render a fleet practically immune from bombing.

The torpedo plane, however, is a more serious weapon than the bomber, due to its greater flexibility for tactical purposes-torpedoes can be released at various ranges and on any bearing-and due to the fact that (Continued on page 33 )

\section{A Chat with Madame Curie}

\section{What the Discoverer of Radium Thinks of Us and What We Think of Her}

\section{By Austin C. Lescarboura}

THAT virtually impenetrable barrier placed about 1 Madame Curie since the very day of her arrival in New York City and resolutely maintained against re-
peated but futile onslaughts of press photographer, newspaper reporter, special writer and technical journalist alike, was removed for a few hours on the eve of her departure for France. All our previous efforts to reach the discoverer of radium were absolutely wasted. But on June 24th, the day prior to her sailing on the "Olympic" with her precious gram of radium, Madame Curie granted us an interview at the home of Madame Curie granted us an interview at the
her hostess, Mrs. Meloney, in New York City.

First of all, let us hasten to assure the gentle reader that Madame Marie Sklodowska Curie is not one who would set herself apart from the public. This matter of refusing to grant interviews and pose for almost countless press photographers was not one of her own choosing. It was an imperative measure arising out of her poor state of health. And when it is borne in mind that the workings of the modern press and news picture machinery are such as even to wear out robust persons, we can readily see the justice of the barrier thrown about Madame Curie.

She carries honor and fame gracefully, this wonderful woman. For despite the fact that Madame Curie had fifty-five degrees from numerous universities, colleges, laboratories and other institutions before coming to this country, to which must be added ten more degrees conferred upon her by American universities and colleges during her seven-week sojourn in these United colleges during her seven-week sojourn in these United
States, Madame Curie remains-and always will remain-just plain Madame Curie.

Unassuming, plainly but neatly dressed, womanly and motherly in appearance, yet keen when the conversation swings to scientific matters, speaking a delightful English that is flavored by what may be a trace of her Polish birth and a good bit of French, her adopted mother tongue-that, in brief, covers the outadopted mother tongue-that, in brief, covers the out-
standing features of Mme. Curie as we saw her, ques- tioned her, listened to her for upward of an hour. Before going ahead with Madame's little talk with us, it may be well to run over the major details of her all-too-brief stay in America. Madame Curie came here from France on May 11th last in order to receive a gram of radium-the gift of the American women in recognition of her services to science and humanity. The gram of radium was presented to her by President Harding on May 20, 1921, at the White House. Between May 11th and June 25th, the day of her departure, Madame Curie visited most of our leading universities, colleges, laboratories, Government bureaus, cities and natural wonders.

As already stated, ten degrees were conferred upon her in recognition of her contributions to science and humanity. Smith College conferred the degree of Doctor of Science; Doctor of Medicine was conferred by the Woman's Medical College; the University of Pittsburgh conferred two degrees, Doctor of Science and Doctor of Laws; Yale, Columbia, Chicago, Northwestern, and Wellesley conferred Doctor of Science; and ern, and Wellesley conferred Doctor of Science; and
Doctor of Philosophy came from the University of Pennsylvania.

Aside from honorary degrees Madame Curie received numerous other distinctions. Thus the Philosophical Society awarded her a gold medal, which carries a money award of $\$ 800$. The Naples Table Award of $\$ 2,000$ also went to Madame Curie, as well as the Willard Gibbs Medal for scientific achievement, which, it is said, has never been awarded to any other woman. This famous scientist was also made Fellow of various technical societies. But despite it all, she remains just plain Madame Curie, working for the good of humanity and for the expansion of scientific knowledge.

Madame Curie likes America-who wouldn't? She was highly impressed by what she saw and heard at the various American universities and colleges which she visited. While not willing to commit herself to a she visited. While not willing to commit herself to a
definite statement regarding the relative merits of
European and American institutions of learning, Madame Curie believes that we have excellent facilities
for training our youth for every line of endeavor. The girl colleges pleased her immensely, and she commented most favorably on the fact that many of our girl colleges-Bryn Mawr, Vassar, Wellesley, for instance-are located in the country, which is more conducive to good health and quiet study. But greatest of all, in Madame Curie's opinion, are our free institutions of learning, especially in such centers as New York City, where the lack of financial means need not necessarily stand in the way of the ambitious boy or girl desiring an academic training.

Both from within and without, we Americans have got into the habit of believing that little we do is done for anything else than to make money. But our dollar-chasing habits have been grossly exaggerated, so it seems. For we asked Madame Curie if she found our scientific laboratories interesting, and she replied that she did. Following that, we asked, in a somewhat abashed way, if she thought we were contributing anything to science, instead of taking science and molding it into the ways of industry for the pure and sole purpose of making money.

Here is the answer: startling, to be sure, but nevertheless true. Madame Curie believes that much of the work done in our leading laboratories and universities is done for the sake of science-pure science-and does not contain the slightest trace of industrial motives. Our Government laboratories are doing wonderful work in many different directions for the good of science and humanity at large, and with the dollar sign conspicuous by its very absence. Truly, we are not the money grabbers or dollar chasers that we have been made out to be by others as well as in our own minds. Still, there is something wonderful about our industrial prowess. Madame Curie was delighted with our development of the radium industry; indeed, we have (Continued on page 35 ) 
The Giant Junk Yard

(Continued from page 20) into the ground just alongside the mountain of scrap, which is brought in from all over the country and unloaded by magnets-it is tin-plate with an iron base, of course. The shavings are forced into the chamber of the press and compressed into a block eight by twelve by twenty inches. In this form manufacturers buy the stuff for resmelting. Thousands of tons of it are used every year.

The Philadelphia company has been best known to the general public for its marine work in salvaging vessels, because of the spectacular nature of this pursuit and the fact that famous old fighting ships fall into its hands. Its specialty, however, is the purchase of any kind of metal junk that the ordinary dealer is not equipped to handle. The company will buy the lightest or the heaviest scrap in the world. It has torn down hundreds of bridges. Recently its workmen swept away every trace of the old Columbia Bridge over the Schuylkill River at Philadelphia in less than sixty days. This iron structure was put up at the time of the Centennial Exposition and has now been replaced with modern bridge.

The firm also buys railroads and trolley lines-including everything from ties to power plant. A single sixteen-wheel trolley car now stands on a side track in the yard to bear witness that there was once a trolley line called the Cape May, Delaware Bay and Sewell Point Railroad, with eighteen miles of track, its own power station and right of way and twenty cars. The junkman bought everything but the right of way, repaired and sold some of the cars, smashed and cut up the others for remelting, dismantled the plant and scrapped most of the equip ment. The company also bought and dis-
mantled the electric railroad from mantled the electric railroad
bury, Conn., to Harlem, N. Y.

bury, Conn., to Harlem, N. Y.
Since the ending of the World War this concern has been perhaps the largest buyer in the country of metal ranging from the vicious four-point barbed wire to shell. Recently the last of the shell castings, totaling about twenty-five thousand tons, was shipped to a firm at Glasgow, Scotland, to be melted and used in the manufacture of machinery and tools. All other war material except about four hundred miles of barbed wire and a large number of hydraulic presses built at a cost of $\$ 10,000$ each to compress powder has been broken up and sold. The barbed wire is being sold to farmers all over the country. It was meant to guard the trenches of the Allies, but it was neve sent abroad.

There is, of course, a large quantity of nickel-steel armor. Most of the tonnage of this kind now in the yard came from the monitor Amphitrite, but there are also some remnants of the battleship "Iowa" in the shape of armor and fighting masts. All of this material is cut up with the oxy-acetylene torch and sent back to the foundries for remelting. Plates and bars of steel and iron that contain no nickel are first cut into handling sizes with the torch, and then chopped up in huge shears the jaws of which will bite through six square inches of steel.

In general it may be said that there is no specific use for the different types of iron and steel scrap. All of it goes to the foundry and the steel plants to be melted over again. It is the practice in these mills to use the old metal in combination with a new ore-just as reworked wool is used with new wool in the making of
clothing. It is then clothing. It is then used in the manufac-
ture of machinery-even in tools that are ture of machinery-even in tools that are put to hard use. No one knows just what
form the locomotive may take after the form the locomotive may take after the junk dealers have broken it into sizes
suitable for the furnaces. Parts of it may go back into the same service and other parts may go into bridges or skyscrapers.

In some cases, however, the concern has discovered specific markets. It is the custom of wire mills, for instance, to draw wire to a certain bundle-length, and frequently an ingot from which the wire is being drawn will not be large enough to complete the last bundle. At other times the wire breaks. This results in what are alled "shorts," which are sold as scrap. The junk yard contains about a thousand miles of this wire, for which a ready market has been found only within the last few years. Inquiry throughout the world brought to light the fact that three or four Chinese and Japanese firms are buyers of this material. They dispose of it in small lots to native metal workers who elties. definite specifications for what they want. They buy one hundred tons of used American horse shoes at a time, for instance and these are melted up by the smiths and used in making razors, pen knives and ovelties.

The scrap yard has a sky line all its own to one walking between the towering piles of metal junk. One such pile consist of all sorts of curious shapes, some of which weigh forty and fifty tons. These are the "skulls" from steel plants, which is the name given to metal that runs over the top of the mold, or the metal which hardens in a furnace because of an accident. The total amount of this steel in any one plant is too small for the manufacturing company to bother with. Skulls accordingly are bought by this

A fi for the furnaces. mast is used for most of the breaking up. Under this treatment the stoutest boiler or other piece of machinery soon becomes un recognizable and ready for the fire that this reconvert it into something useful. In that is susceptible of salvaging. The company operates a machine shop where locomotives, road rollers, sewing machines and virtually everything else that can be induced to move is rebuilt, where possible,
and sold for continued use. A large perand sold for continued use. A large per centage of the metalplate scrap obtained in used for the manufacture of washers pany made all the washers used in the construction of the Panama Canal.

Some of the workmen engaged in the dismantling of plants become as expert as lumber jacks in their own line. It is a boast of the company that its men can any given stack within five feet of used for this work. Foundations are cut away on one side and dynamite is used in some instances. Where that is impracticable foundations are replaced with tim-
ber underpinning until the stack can be expected to topple of its own weight when these are removed. The timbers are then burned away. For tearing down gas holders the company uses a special axe which cuts through wroug

A metal junk yard may be likened to a history of the early days of industry. But it touches other things besides the romance of business. The company, some years ago, dismantled the power house dynamos used to execute the first of the New York gunmen are now serving some useful purpose. They were dismantled, broken up and sold to be remelted. Soone or later some use is found for every pound of metallic scrap that is kept off the dump heap.

\section{Weapons at Sea} (Continued from page 25) torpedo hits are, generally, in spots un protected by armor. Again, in the case of torpedoes, the explosive effect is enhanced by the inertness of water, for, by plosion is transmitted to the attacked ship's hull.

(Continued on page 35)

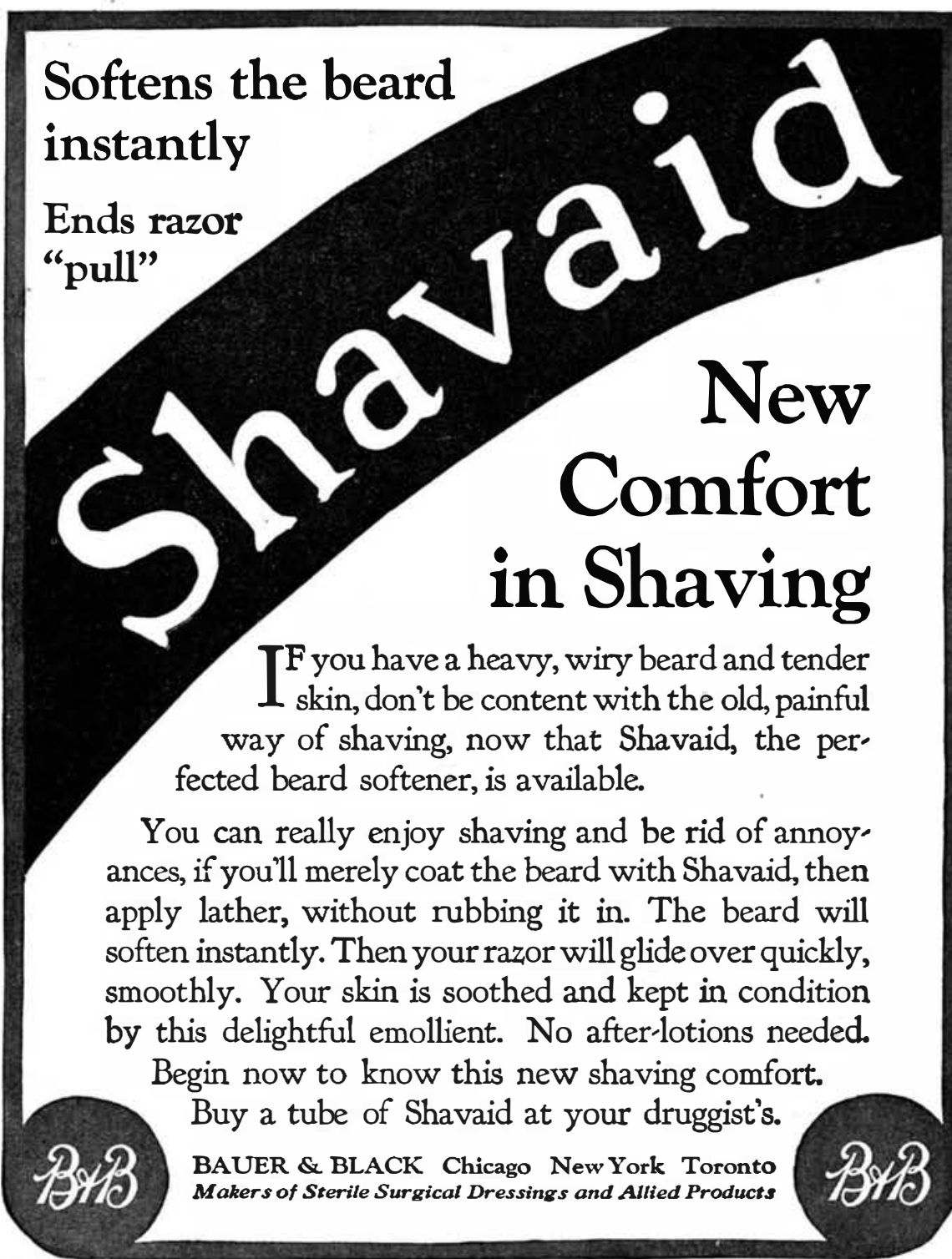

Experimental and Model Work Fim thacHINES Corliss Engines, Brewers

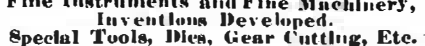

HENRY ZUHR, 489-93 Broome St., New York City BEATS I5c GASOLINE Increases Power and mileage 40\% The VILTER MFG. CO.
989 Clinton Street For Gunsmiths, Tool Makers, Experimental \& Repair Work, etc.

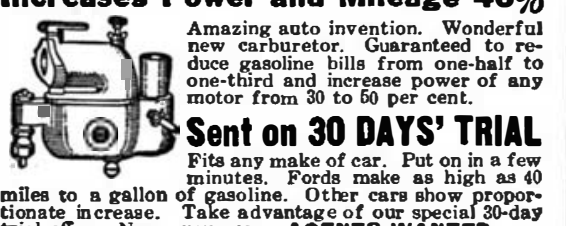
Name your car AGEMTS WANT AlR FRICTION CARBURETOR CO.;

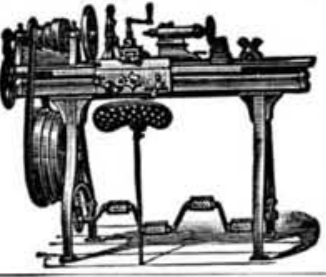
From9-in. to 18-in. swing. Arranged for Velocipede or Stand up Treadle. W. F. \& J. Barnes Co 1999 Ruby Street
Rockford, III.

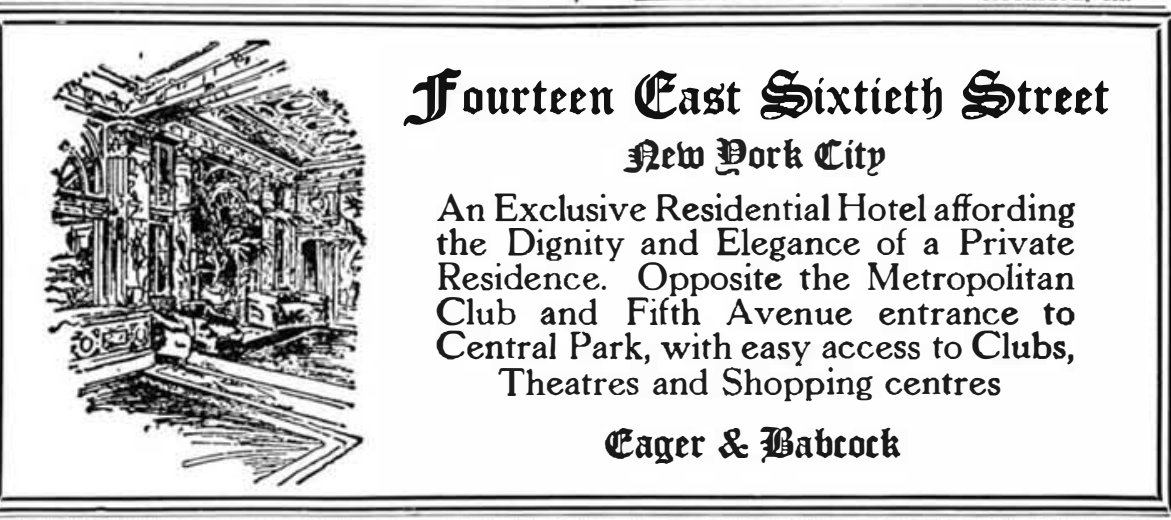

EXACT SIZE AND STYLE - LETTERS \& FIGURES 214

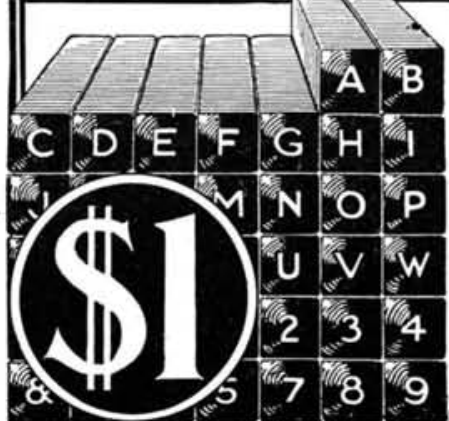

Identify Your Own Property U. S. Army Stamping Set

Of thirty-seven steel lettersand figuresmade for U.S. Government to stamp soldier's equipment. Suitable for marking tools, wood, leather, steel and slightly less than $1 /$ inch, Sent post paid, anywhere in United States for $\$ 1.00$

FRANCIS BANNERMAN SONS 501 Broadway Est. 1865 New York City hol Prope Mlustrated 1920 Reference
Catalog Mailed 500 c 1921 Circular 100 


\section{Weapons at Sea}

(Continued from page 33)

In considering the case of the capital ship, it must not be taken as a unit, but as a craft of great offensive power for gaining control of the sea, but which has a number of agencies, protective and offensive, to assist and protect it. If the protective agencies are allowed to lag behind the development of a new arm there is no occasion for hysteria concerning the passing of the capital ship; instead, there must be concentration on the provision of defense measures to meet the new menace. As in the past, you did not send out a battleship devoid of armor; and as in the present you give her a destroyer screen against submarines; so, in ice of fighting aircraft.

Notwithstanding all the hysteria concerning the passing of the capital ship as a type, it must be remembered that the cheapest and most powerful unit weapon is the gun. It hurls explosives in large quantities at enormous velocity. The battleship is the type developed to use it at sea. And, the battleship or some other type adopted to carry this weapon, with protection inherent in itself, or in supporting types, against the menace from the and subsurface, will always con trol the warfare as long as commerce moves in warfare as long as commerce moves in
surface ships. Should commerce in bulk surface ships. Should commerce in bulk and enormous quantities ever move by air, then, and only then, shall we see the batat sea.

However, the havoc made by the submarine against sea-borne commerce in the last war will be duplicated from the air in the next war, if defensive measures ar not devised and provided to meet it. As in this war with hostile submarines, so in the next, with hostile aircraft, any country will be at a great disadvantage if admerce is not at hand.

Aircraft, used as a destructive agency in a sea battle, can be largely discounted as a determining factor, for nullifying provisions will be made, aerially, by both sides before such a battle is initiated. But the use of aircraft on a large scale against plication as the submarine unless measures are at hand for defense, namely, antinircraft guns and counter-air-defense. The inability of the aircraft to operate for long periods without the assistance of floating or land base will mitigate against its use and value. However, the merchant convoy of the next war will need two or more anti-aircraft guns on each ship, and one or more fighting planes on deck, especially when within 300 miles of the enemies' bases. If control of the sea is not already obtained, or if the enemy has carriers or men-of-war at sea, to be used as raiders, merchant ships must carry aircraft at all times.

The fanaticism of the air force advocates is not warranted so far as it calls for the destruction and abolition of surface types, particularly men-of-war or merchant vessels. Economy largely determines trade routes and methods of carriage. Both are susceptible of modification in time of war. Sea-borne commerce, for long hauls, will always, in peace time be carried in surface craft, since such craft are and must be for this and the next generation the cheapest method of in war time, an economic shortage of fuel or military supplies by air transport or sub-surface craft. An adequate number of such craft would not be built in peace time because of expense.

In war time a cause, already lost, might attempt as a last expedient to stem the craft freighters whe such straws as airbe a determining factor in resisting ecobe a determining factor in resisting eco-
nomic shortage when control of the sea is lost.
A Chat with Madame Curie (Continued from page 25)

made an industry of it. Our radium proction surpasses by far that of any other country. We have found almost countless
ways of putting radium to work, such as ways of putting radium to work, such as lluminating watch dials, locator buttons, un sights, instrument dials, and so on And what satisfaction for Madame Curie to learn, as she very quickly learned, that our methods of extracting radium from carnotite ores of Colorado are prehusband long since deceased, and herself mployed in a modest laboratory back some two decades ago when radium was first isolated and studied by itself!

Despite twenty years of study and reearch devoted to radium and radioacthity, Madame Curie admits that she has much to learn. And if she knows very ific studies, who does? Radium, she tells us, must be handled with great care. areless or inexperienced handling may prove dangerous and perhaps fatal. We
noted that one of her hands had bee noted that one of her hands had been affected by the radioactive rays and her eneral health, so she told us, had been wartime work with radium.

But what will Madame Curie do with her gram of radium, now that she has
realized the wish of her life time? That is a difficult question to answer. Even brief discussion on radium and radio active properties soon leads to an impentrable jungle of technology, throug which the inexperienced layman cannot
hope to pass. So Madame Curie, with modest smile, could not tell us just what modest smile, could not tell us just what
she intended to do with the precious gram. she intended to do with the precious gram. Institute in Paris divides its efforts alon two main lines, namely, physicochemical and physicobiological, as she terms them. The former has to do with the study of radium and radioactive substances purely rom the standpoint of the physicist, while the latter deals with their application to the treatment of human ailments. Madame Curie impressed us as being as much interested in one as the other. Answers
to a few medical questions made us feel that her Doctor of Medicine degrees have been most appropriately awarded.

However little Madame Curie may be able to explain to us as regards her future work with said gram of radium, one thing is certain, and that is that she
needs rest and plenty of it. She told us the first part of her program called for protracted rest, extending through July will be back in the Curie Institute, she at work on the gram of radium. Furthermore, she intends to carry on an extensive investigation with a large quantity mesathorium, another radioactive sub-
stance, which she has taken back with her. stance, which she has taken back with her.
It was a mighty tired but highly grateful and appreciative woman that sailed for France on June 25th. Down in that holy of holies - the specie room-of the "Olympic" was her precious gram of radium and a quantity of mesathorium, valued at $\$ 165,000$ in all. Special precautions had to be taken on account of the ship's instruments, for the compasses mist not be disturbed in their normal functions. The Bureau of Standards carried out the hogany case lined with lead and steel was provided. Although the box was not large, it weighed, with these linings, 130 pounds. Directly in the center of the box were several small compartments, formed of lead and surrounded by steel, each one of the right size to admit a small glass tube containing a portion of the radium
salts - the form in which the metal is han dled for shipment. The lid of the mahogany box was inlaid with a gold plate handsomels marked with the following inscription: "Presented by the President of the United States on behalf of the women of America to Madame Marie Sklodowska Curie in recognition of her transcendent service to science and humanity in the discovery of radium. The White House, May 20, 1921."

\section{Counting Bacteria}

(Continued from page 29)

law. The two circuits form in the ocular field two adjacent layers which the obbased either on polarization phenomena produced by glass prisms, or else by the gradual displacement of a dimming plate. In the new opacimeter the luminous source is a nitrogen lamp of 100 candlepow contained in a metallic globe, allar directions. lel pencil through two windows diametrically opposed in the side of a copper recipient full of water destined to receive the emulsion tube. On going out, the pencil, after having passed through a selective colored screen, penetrates a totalreflection prism and then forms into a lens which throws the ray upon a glass cube formed by two right-triangutar nuses, one of which, partially silvered, throws it finally into the microscope. The other pencil of light follows through the colored screen and passing through an ob-
jective it traverses the glass cube through its non-silvered part and subsequently penetrates into the field of the ocular of the microscope. Before penetrating into the objective this luminous ray passe lhrough a photographic plate, more or having been previously determined by means of spectrophotometric measures.
This plate, mounted on a glass cylinder, pivots upon its center by the action of a little handle which the observer actuates from the outside, and has a photographic scale dividing its length into 100 tics of the objective have been calculated so that the image of the divisions shall be formed on the level of the silver surface of the glass cube so that it may be seen in the microscope at the same time as the limit of the two layers. The equaling of is therefore made in the same field. In order that the observer be not influenced by any preconceived idea, a handle allows him to actuate a movable shutter which reveals the graded scale at the exact moment needed.

As the gradual dimness of this photographic plate or screen is measured by necessary to arbitrary graduation, it is tion. For that purpose a curve is constructed connecting the divisions to the standard chosen as representative of bacterian substance, such as for example the dry weight of bacteria per cubic centimeter of emulsion.

After having taken as a standard a bactwo parts. apparatus and the mixture at the bottom is drawn off and washed in distilled water, when it is weighed at 110 degrees. Thus, the net weight in milligrams per cubic centimeter of standard emulsion is obtained. With the other part a series of emulsions is made up which are succesBy using the amounts read out as abscissas and the corresponding dry weights as ordinates, the calibration curve is obordinates, the calibration curve is ob-
tained. In the laboratory the strength of the serums is not expressed in dry weight but by the number of bacteria per cubi centimeter and, therefore, after having
obtained the standard, microscopic counts obtained the standard, microscopic counts Lastly, from time to time, the various adjustments of the apparatus are verified by means of opal-colored glass plates disposed in tubes and which are used for posed in tubes and whic
constant opacity tests.

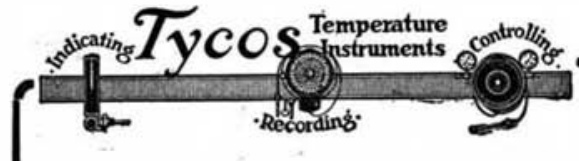

To solve temperature problems thoroughly-indicating, recording or controllingadd the experience of the Tycos organization to the resources of your own staff.

Specific information without obligation
or delay if you give firm consection
when writing.

Faylor Instrument Companies Rochester, N. Y.

There's a Toas or Torter Temperature Instrument

Weber Crank-Pin Re-Turning Tool

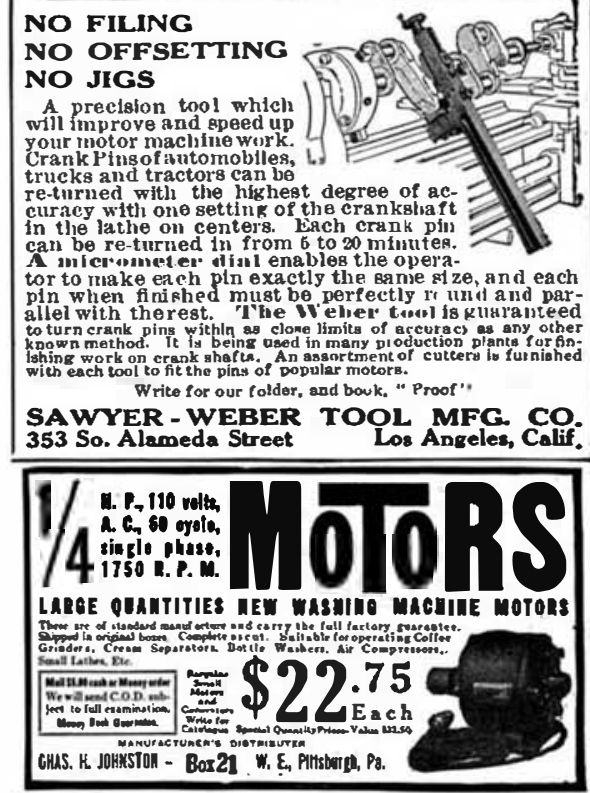

We Will Make It

Anything in a metal stamping or novelty pro-
duced from any metal and finished in any color. Waterbury Button Co., Waterbury, Conn

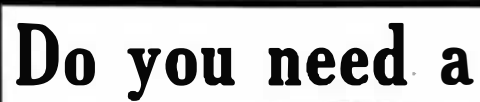
Light Power Unit?

Write at once for infor markable little gasoline engine.

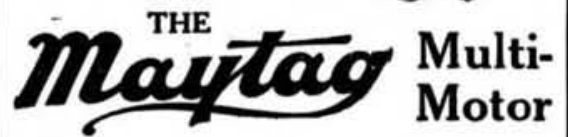

